\title{
Ineffectiveness of hepatitis B vaccination in cirrhotic patients waiting for liver transplantation
}

\author{
Edith Villeneuve ${ }^{1}$, Jean Vincelette $\mathrm{MD}^{2}$, Jean-Pierre Villeneuve $\mathrm{MD}^{1}$
}

E Villeneuve, J Vincelette, JP Villeneuve. Ineffectiveness of hepatitis $B$ vaccination in cirrhotic patients waiting for liver transplantation. Can J Gastroenterol 2000;14(Suppl B):59B62B. Cirrhotic patients who undergo liver transplantation are at risk of acquiring de novo hepatitis B virus (HBV) infection at the time of transplantation. It is common practice to immunize these patients against $\mathrm{HBV}$, but the efficacy of vaccination is uncertain. The response to vaccination with a recombinant HBV vaccine was examined in 49 patients with cirrhosis before liver transplantation. Patients received three doses $(20 \mathrm{~g})$ of Engerix-B (SmithKline Beecham) at zero, one and two months before transplantation, and their response was measured on the day of liver transplantation (9.3 1.2 months after the initial dose of vaccine). Results were compared with those reported in healthy adults vaccinated according to the same schedule. Fourteen of 49 cirrhotic patients $(28 \%)$ developed antibodies to hepatitis B surface antigen (anti-HBs) levels of more than $10 \mathrm{U} / \mathrm{L}$ after vaccination compared with $97 \%$ of healthy controls. Four patients $(8 \%)$ had anti-HBs levels of more than $100 \mathrm{U} / \mathrm{L}$ compared with $83 \%$ in healthy individuals. Mean anti-HBs titre in the 14 responders was $62 \mathrm{U} / \mathrm{L}$ compared with $348 \mathrm{U} / \mathrm{L}$ in controls. No factor was identified that predicted response to vaccination. One of 49 patients acquired de novo HBV infection at the time of liver transplantation. Current HBV vaccination of cirrhotic patients waiting for liver transplantation is ineffective, and new strategies need to be developed to increase the response rate.

Key Words: Cirrhosis; Hepatitis B vaccination; Liver transplantation

\section{Inefficacité de la vaccination contre l'hépatite B chez les patients cirrhotiques en attente d'une greffe du foie}

RÉSUMÉ: Les patients cirrhotiques qui subissent une greffe du foie sont exposés au risque de contracter une infection de novo au virus de l'hépatite $\mathrm{B}$ (VHB) au moment de la transplantation. Il est d'usage courant d'immuniser ces patients contre le VHB ; cependant, l'efficacité de la vaccination reste incertaine. La réponse à la vaccination avec un vaccin recombinant contre le VHB a été examinée chez 49 patients atteints de cirrhose avant une greffe du foie. Les patients ont reçu trois doses $(20 \mu \mathrm{g})$ de Engerix-B (SmithKline Beecham) à zéro, un et deux mois avant la greffe, et leur réponse au vaccin a été mesurée le jour de la transplantation $(9,3 \pm 1,2$ mois après la dose initiale de vaccin). Les résultats ont été comparés à ceux rapportés sur des adultes sains vaccinés selon le même calendrier. Quatorze des 49 patients cirrhotiques ( $28 \%$ ) ont développé des niveaux d'anticorps à l'antigène de surface de l'hépatite $B($ anti-HBs) supérieurs à $10 \mathrm{U} / \mathrm{L}$ après la vaccination comparativement à $97 \%$ dans le groupe des sujets témoins. Quatre patients $(8 \%)$ avaient des niveaux d'anticorps à l'anti-HBs supérieurs à $100 \mathrm{U} / \mathrm{L}$ comparativement à $83 \%$ dans le groupe des sujets sains. Le titre moyen aux anti-HBs chez 14 répondeurs était de $62 \mathrm{U} / \mathrm{L}$ comparativement à $348 \mathrm{U} / \mathrm{L}$ dans le groupe témoin. Aucun facteur, pouvant prédire la réponse à la vaccination, n’a été identifié. Un des 49 patients a contracté une infection de novo au VHB au moment de la greffe du foie. La vaccination actuelle contre le VHB chez les patients cirrhotiques en attente d'une greffe du foie n'est pas efficace ; par conséquent, de nouvelles approches s'imposent pour augmenter le taux de réponse à la vaccination.

\footnotetext{
${ }^{1}$ Division of Hepatology and ${ }^{2}$ Microbiology, Centre Hospitalier de l'Université de Montréal, Campus Saint-Luc, Montréal, Quebec

Correspondence and reprints: Dr Jean-Pierre Villeneuve, Liver Unit, Centre de recherche du CHUM, Campus Saint-Luc,

264 east René-Lévesque blvd, Montréal, Québec H2X 1P1. Telephone 514-281-2446, fax 514-281-2492

Received for publication May 3, 1999. Accepted October 28, 1999
} 
$\mathrm{P}$ atients undergoing orthotopic liver transplantation (OLT) are considered to be at risk of acquiring hepatitis $\mathrm{B}$ virus (HBV) infection during the perioperative period from transfused blood products or from the donor liver (1-3). In contrast with the low risk of chronicity of acute HBV infection in immunocompetent adults, de novo HBV infection after liver transplantation almost always progresses to chronicity (3). Because of this risk, most liver transplantation programs immunize patients waiting for transplantation against $\mathrm{HBV}$. In healthy individuals, hepatitis $\mathrm{B}$ vaccination is highly effective, with protective serum titre of antibodies to hepatitis B surface antigen (anti-HBs) of more than $10 \mathrm{UH}$ developing in $95 \%$ to $99 \%$ of subjects administered a series of three doses of either plasma-derived or recombinant vaecine. The response rate of $\mathrm{HBV}$ vaccination of individuats awaiting liver transplantation appears not to be as effective (4-7).

In the present study, we examined the efficacy of hepatitis $B$ vaccination in patients with cirrhosis listed for liver transplantation at our institution, and we sought factors that could predict the response to vaccination.

\section{PATIENTS AND METHODS}

A retrospective study of patients who underwent liver transplantation at the authors' institution was carried out between September 1991 and May 1998. Inclusion criteria were: received a liver transplantation for cirrhosis of the liver; had a negative serology for hepatitis B surface antigen (HBsAg) and anti-HBs before vaccination; received three doses of recombinant vaccine against hepatitis B (Engerix-B, 20 g; SmithKline Beecham, Philadelphia, Pennsylvania) at zero, one and two months before transplantation, with the last dose at least one month before liver transplantation; and had a serum obtained on the day of liver transplantation and stored at $-20 \mathrm{C}$.

The following information was recorded from the charts of eligible patients: age, sex, etiology of cirrhosis, severity of liver disease as assessed by the Child-Pugh score (8), presence or absence of hepatocellular carcinoma, serum creatinine, and presence or absence of serum antibodies to the core antigen of HBV (anti-HBc).

In the sera obtained on the day of liver transplantation, anti-HBs levels were measured by an enzyme-linked immunosorbent assay (ELISA) (Cobas Core Anti-HBs Quan EIA, Roche Diagnostics, Basel, Switzerland). Results in cirrhotic patients were compared with those of 113 healthy adults who had received hepatitis B vaccine according to the same vaccination schedule and in whom anti-HBs levels were measured seven months after the initial dose of Engerix (9). Differences between groups were assessed by the Mann-Whitney test for continuous variables and by Fisher's exact test for categorical variables. $\mathrm{P}<0.05$ was considered significant.

\section{RESULTS}

Forty-nine patients were included in the study. Their clinical and biochemical characteristics are summarized in Table 1. The interval between the first dose of vaccine and measurement of anti-HBs on the day of liver transplantation av-
TABLE 1

Characteristics of 49 patients immunized against hepatitis $B$ before liver transplantation

\begin{tabular}{lc}
\hline Age (years) & 492 \\
Sex (male/female) & $32 / 17$ \\
Etiology of cirrhosis (n) & 17 \\
Alcoholic & 7 \\
Primary biliary cirrhosis & 6 \\
Hepatitis C & 5 \\
Cryptogenic & 5 \\
Primary sclerosing cholangitis & 2 \\
Autoimmune hepatitis & 2 \\
alpha, antitrypsin deficiency & 2 \\
Budd-Chiari syndrome & 1 \\
Hemochromatosis & 1 \\
Wilson's disease & 1 \\
Secondary biliary cirrhosis & \\
Child-Pugh score (n) & 0 \\
Class A & 16 \\
Class B & 33 \\
Class C & \\
\hline
\end{tabular}

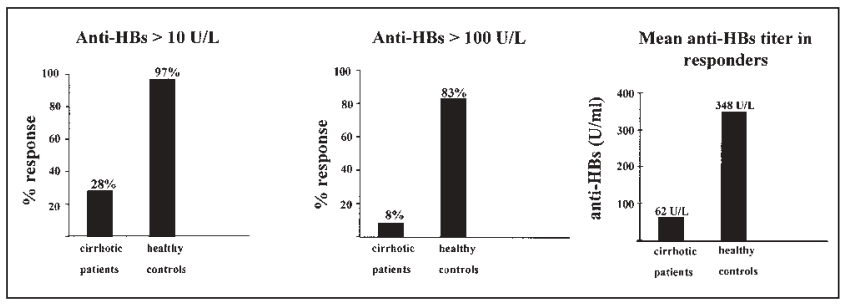

Figure 1) Response to hepatitis B vaccination in cirrhotic patients awaiting liver transplantation compared with response in healthy controls. Anti-HBs Antibodies to hepatitis B surface antigen

eraged 9.31 .2 months. The response to vaccination is shown in Figure 1. The proportion of cirrhotic patients who developed anti-HBs levels greater than $10 \mathrm{U} / \mathrm{L}$ or greater than $100 \mathrm{U} / \mathrm{L}$ was significantly lower compared with results from healthy controls $(\mathrm{P}<0.05)$. In the 14 patients who responded to vaccine (ie, anti-HBs level greater than $10 \mathrm{U} / \mathrm{L}$ ), the mean anti-HBs titre was significantlylower than that of healthy controls $(\mathrm{P}<0.05)$. When patients who responded to vaccination were compared with those who did not, no factor was identified that predicted the response to vaccination (Table 2).

Chalasani et al (7) reported a better response to vaccination in patients with cholestatic liver disease compared with those with noncholestatic liver disease, but the data from the presented study do not confirm this; two of 13 patients (15\%) with cholestatic liver disease responded to vaccination compared with 12 of 36 (33\%) in those with noncholestatic liver disease (not significant). 
One of 49 patients (2\%) acquired HBV infection at the time of liver transplantation and became a chronic carrier of the virus. She had not responded to hepatitis $B$ vaccination before liver transplantation. This risk of acquiring hepatitis $B$ at liver transplantation is comparable with that reported in other series (Table 3 ).

\section{DISCUSSION}

The frequency of de novo hepatitis in liver transplant recipients is about $2 \%$ to $3 \%$. Acquisition of hepatitis B from transfusion of blood or blood products occurs despite screening, but the risk is exceedingly low - estimated to be one in 63,000 (10). The use of livers from donors without serum $\mathrm{HBs} \mathrm{Ag}$ but with positive serum anti-HBc is a major risk factor for de novo post-transplantation hepatitis $B$ infection $(2,11)$. Reactivation of an occult HBV infection in the recipient has also been reported after liver transplantation (1). Of course, patients can also acquire HBV infection in the post-transplant period because of lifestyle risks.

De novo HBV infection after liver transplantation appears to differ markedly from allograft reinfection after transplantation for chronic HBV cirrhosis. In the latter instance, recurrence of $\mathrm{HBV}$ infection is a serious problem with a rapid evolution and a high mortality (12). Patients with de novo $\mathrm{HBV}$ infection after transplantation rarely clear $\mathrm{HBsAg}$, but the evolution of the infection appears rather indolent with good long term survival $(1,3)$. Several hypotheses have been proposed to explain the disparity of the clinical course between de novo HBV infection and HBV recurrence, including size of the infectious inoculum, degree of immunosuppression during the acute hepatitis phase and the underlying host immunocompetence to the HBV (13).

Most liver transplantation programs routinely immunize OLT candidates against hepatitis B to prevent de novo infections. Recombinant hepatitis vaccines induce seroprotective levels of anti-HBs in $95 \%$ to $99 \%$ of healthy individuals, but our data indicate that vaccination with a standard dose of recombinant vaccine is ineffective in patients with severe cirrhosis because only $28 \%$ of cases developed an anti-HBs level above $10 \mathrm{U} / \mathrm{L}$, and only $8 \%$ had levels greater than $100 \mathrm{U} / \mathrm{L}$.

Similarly, poor response rates to HBV vaccination have been reported by other investigators using plasma-derived or recombinant vaccine (4-7). Chalasani et al (7) also reported that the response to HBV vaccination after successful transplantation is even less than that of candidates awaiting liver transplantation $(6.7 \%$ versus $16 \%$, respectively). Poor response rate to $\mathrm{HBV}$ vaccination have also been reported in patients with chronic renal disease awaiting renal transplantation (14).

Although patients with severe cirrhosis are known to have decreased cellular and humoral immune responses, it is uncertain whether they also respond poorly to other vaccines. McCashland et al (15) have reported a decreased response to pneumococcal vaccine in patients with cirrhosis waiting for liver transplantation. Hepatitis A vaccine induced a satisfactory immune response in patients with com-
TABLE 2

Characteristics of cirrhotic patients who did and did not respond to vaccination

\begin{tabular}{|c|c|c|}
\hline & $\begin{array}{l}\text { Responders } \\
(n=14)\end{array}$ & $\begin{array}{l}\text { Nonresponders } \\
\quad(\mathrm{n}=35)\end{array}$ \\
\hline Age in years (mean SEM) & 523 & 472 \\
\hline (male/female) & $10 / 4$ & $22 / 13$ \\
\hline Pugh score (mean SEM) & 10.90 .6 & 10.30 .4 \\
\hline $\begin{array}{l}\text { Serum creatinine }(\mu \mathrm{mmol} / \mathrm{L} \text { ) } \\
\text { (mean SEM) }\end{array}$ & 11924 & 11321 \\
\hline $\begin{array}{l}\text { Interval between first dose of vaccine and } \\
\text { liver transplant (months) (mean SEM) }\end{array}$ & 9.93 .3 & 9.11 .1 \\
\hline Anti-HBc positive at initial evaluation (\%) & $8 \%$ & $6 \%$ \\
\hline
\end{tabular}

There was no significant difference between responders and nonresponders. Anti-HBC Antibodies to the core antigen of hepatitis $B$ virus

TABLE 3

Risk of acquisition of hepatitis B virus at the time of liver transplantation

\begin{tabular}{lc}
\hline Author (reference) & Number of cases (\%) \\
\hline Present series & $1 / 49(2.0 \%)$ \\
Fabia et al (3) & $13 / 826(1.7 \%)$ \\
Chalasani et al (7) & $4 / 171(2.3 \%)$ \\
Dickson et al (2) & $21 / 674(3.1 \%)$ \\
Chazouillières et al (1) & $20 / 207(9.7 \%)$ \\
\hline
\end{tabular}

pensated chronic liver disease (16), but the response in patients with severe cirrhosis has not been evaluated.

In view of the inefficacy of $H B V$ vaccination and the low risk of acquiring HBV infection after transplantation, the routine use of HBV vaccine as presently done in patients awaiting liver transplantation is questionable. Exclusion of anti-HBc-positive donors for liver transplantation should lead to a reduction in the risk of de novo HBV infection. In addition, alternative strategies to improve the efficacy of HBV vaccination need to be examined. The most obvious one would be to increase the dose of vaccine, as already done in immunocompromised patients (17). Unfortunately, this does not appear to be very effective; a 38\% response rate has been reported with double dose (40 g) of Engerix-B (18).

The use of adjuvants, such as interferon, thymosin or levamisole as primers of the immune systen before or concurrently with the administration-of the vaccine has been proposed, but not tested (19). Third-generation vaccine containing pre-S1 and pre-S2 along with HBsAg may also be more immunogenic in patients with liver disease. A potentially more effective approach would be to vaccinate all patients with chronic liver disease as soon as the diagnosis is established, thereby inducing protection at a time when their immune responses are still functional. This is in line with the current universal vaccination programs already existing in Canada, but the benefits would only be seen years from now. 


\section{CONCLUSIONS}

HBV vaccination of patients with cirrhosis waiting for liver transplantation is ineffective as presently done, and further studies are needed to define ways to increase the response rate. In the meantime, early vaccination of all patients with chronic liver disease seems reasonable.

ACKNOWLEDGEMENTS: Edith Villeneuve was the recipient of a summer studentship from Association Canadienne de l'Industrie du Médicament. This work was supported by grants from SmithKline Beecham Inc and the Medical Research Council of Canada.

\section{REFERENCES}

1. Chazouillères $O$, Mamish D, Kim M, et al. 'Occult' hepatitis B virus as source of infection in liver transplant recipients. Lancet 1994;343:142-6.

2. Dickson RC, Everhart JE, Lake JR, et al. Transmission of hepatitis B by transplantation of livers from donors positive for antibody to hepatitis B core antigen. Gastroenterology 1997;113:1668-74.

3. Fabia R, Levy MF, Crippin J, et al. De novo hepatitis B infection after liver transplantation: source of disease, incidence and impact. Liver Transplant Surg 1998;4:119-27.

4. Carey W, Pimentel R, Westveer MK, Vogt D, Broughan T. Failure of hepatitis B immunization in liver transplant recipients: results of a prospective trial. Am J Gastroenterol 1990;85:1590-2.

5. Van Thiel DH, El-Ashmawy L, Love K, Gavales JS, Starzl TE. Response to hepatitis B vaccination by liver transplant candidates. Dig Dis Sci 1992;37:1245-9.

6. Loinaz C, de Juanes JR, Gonzalez EM, et al. Hepatitis B vaccination results in 140 liver transplant recipients. Hepatogastroenterology $1997 ; 44: 235-8$.
7. Chalasani N, Smallwood G, Halcomb B. Is vaccination against hepatitis B infection indicated in patients waiting for or after orthotopic liver transplantation? Liver Transplant Surg 1998;4:128-32.

8. Pugh RNH, Murray-Lyon IM, Dawson JL, Pietroni MC, Williams R. Transection of the oesophagus for bleeding oesophageal varices. Br J Surg 1973;60:646-9.

9. Marsano LS, Greenberg RN, Kirkpatrick RB, et al. Comparison of a rapid hepatitis $B$ immunization schedule to the standard schedule for adults. Am J Gastroenterol 1996;91:111-5.

10. Schreiber GB, Busch MP, Kleinman SH, Korelitz JJ and the Retrovirus Epidemiology Donor Study. The risk of transfusion-transmitted viral infection. N Engl J Med 1996:334:1685-90.

1. Wachs ME, Amend WJ, Ascher NL, et al. The risk of transmission of hepatitis $\mathrm{B}$ from $\mathrm{HBs} \mathrm{Ag}(-), \mathrm{HBcAb}(+), \operatorname{HBIgM}(-)$ organ donors. Transplantation 1995;59:230-4.

12. Samuel D, Muller R, Alexander G, et al. Liver transplantation in European patients with the hepatitis B surface antigen. N Engl J Med 1993;329:1842-7.

13. Pruett TL. De novo HBV infections after liver transplantation. Liver Transplant Surg 1998;4:182-4.

14. Johnson DW, Flemming SJ. The use of vaccines in renal failure. Clin Pharmacokinet 1992;22:434-46.

15. McCashland TM, Gentry MJ, Preheim LC. Pneumococcal vaccine response is reduced by cirrhosis and liver transplantation. Hepatology 1996;24:305A.

16. Keeffe EB, Iwarson S, McMahon BJ, et al. Safety and immunogenicity of hepatitis A vaccine in patients with chronic liver disease. Hepatology 1998;27:881-6.

17. Lemon SM, Thomas DL. Vaccines to prevent viral hepatitis. N Engl J Med 1997;336:196-204.

18. Horlander JC, Manam R, Boyle N, et al. Efficacy of double dose recombinant hepatitis $B$ vaccine in patients with chronic liver disease awaiting liver transplantation. Hepatology 1998;28:258A. 
19. Van Thiel DH. Vaccination of patients with liver disease: who, when and how. Liver Transplant Surg 1998;4:185-7.

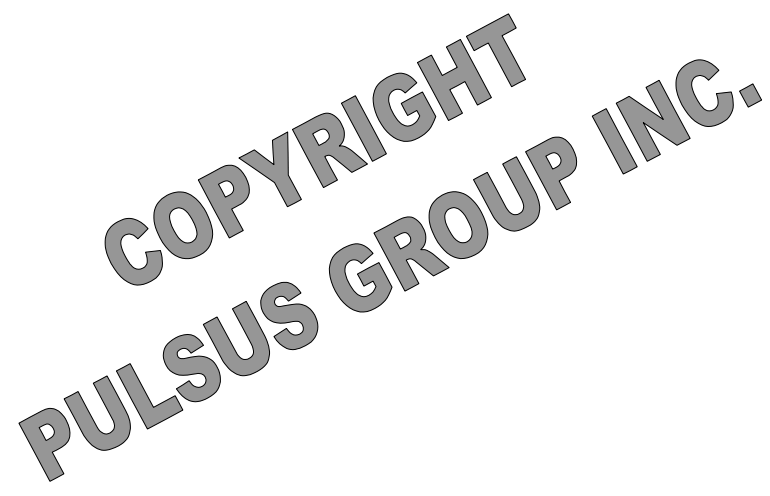




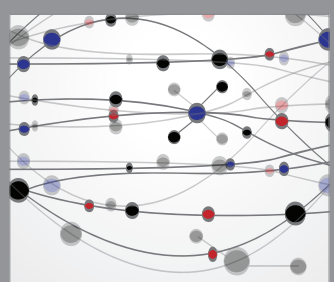

The Scientific World Journal
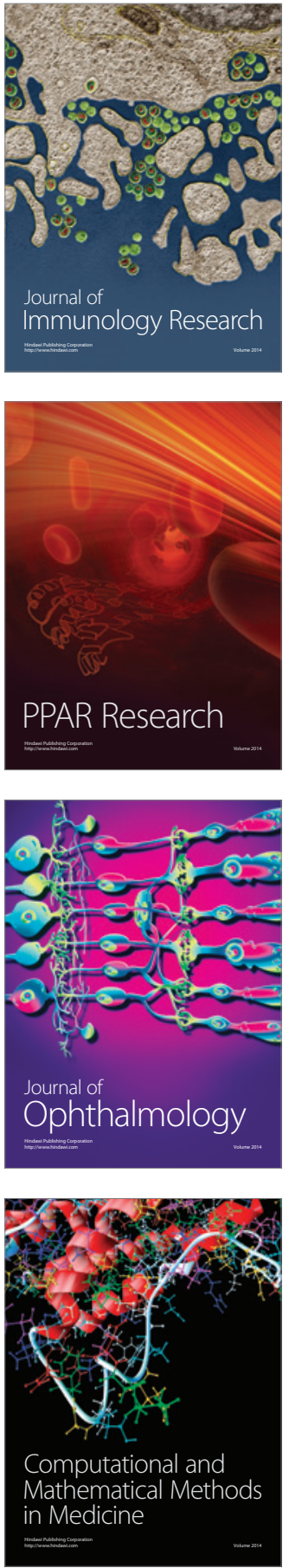

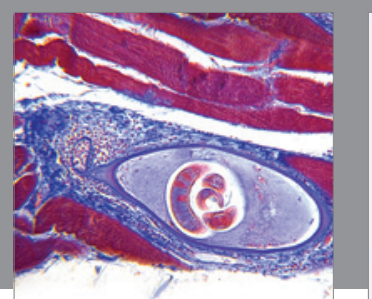

Gastroenterology Research and Practice

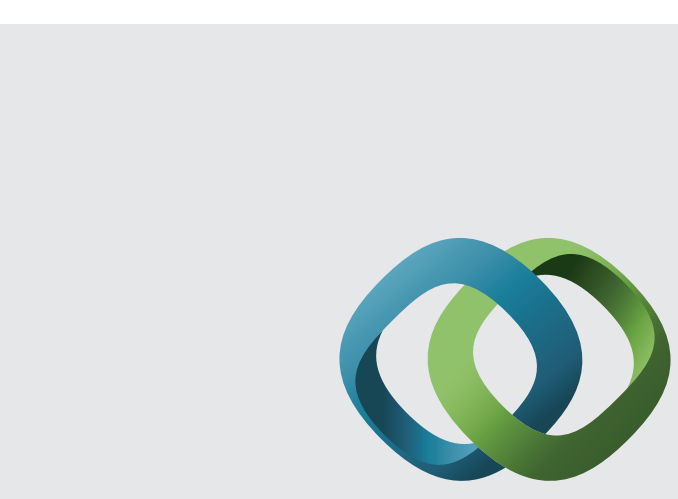

\section{Hindawi}

Submit your manuscripts at

http://www.hindawi.com
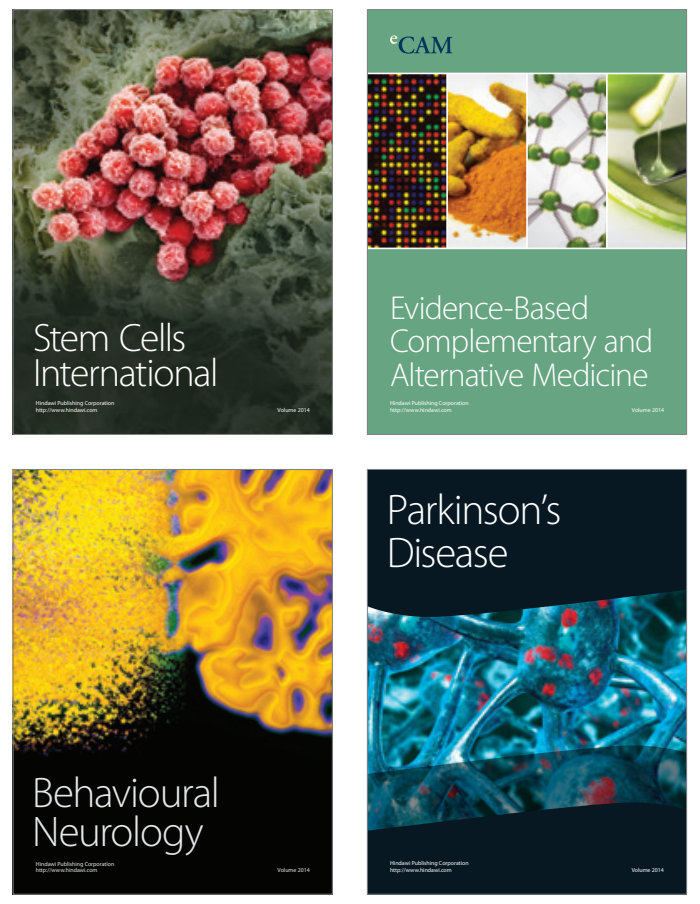
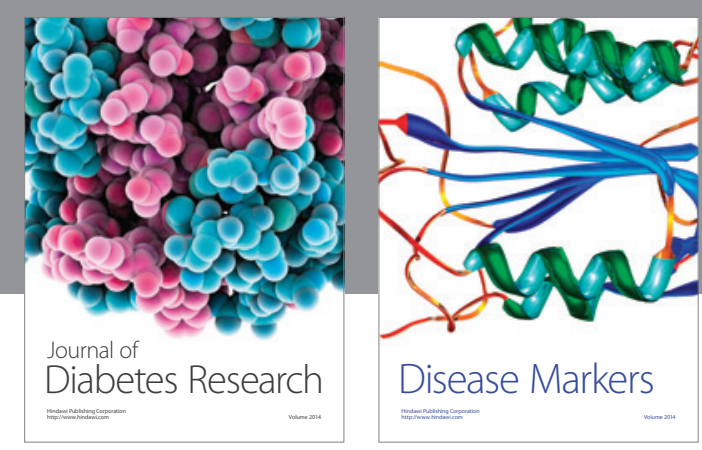

Disease Markers
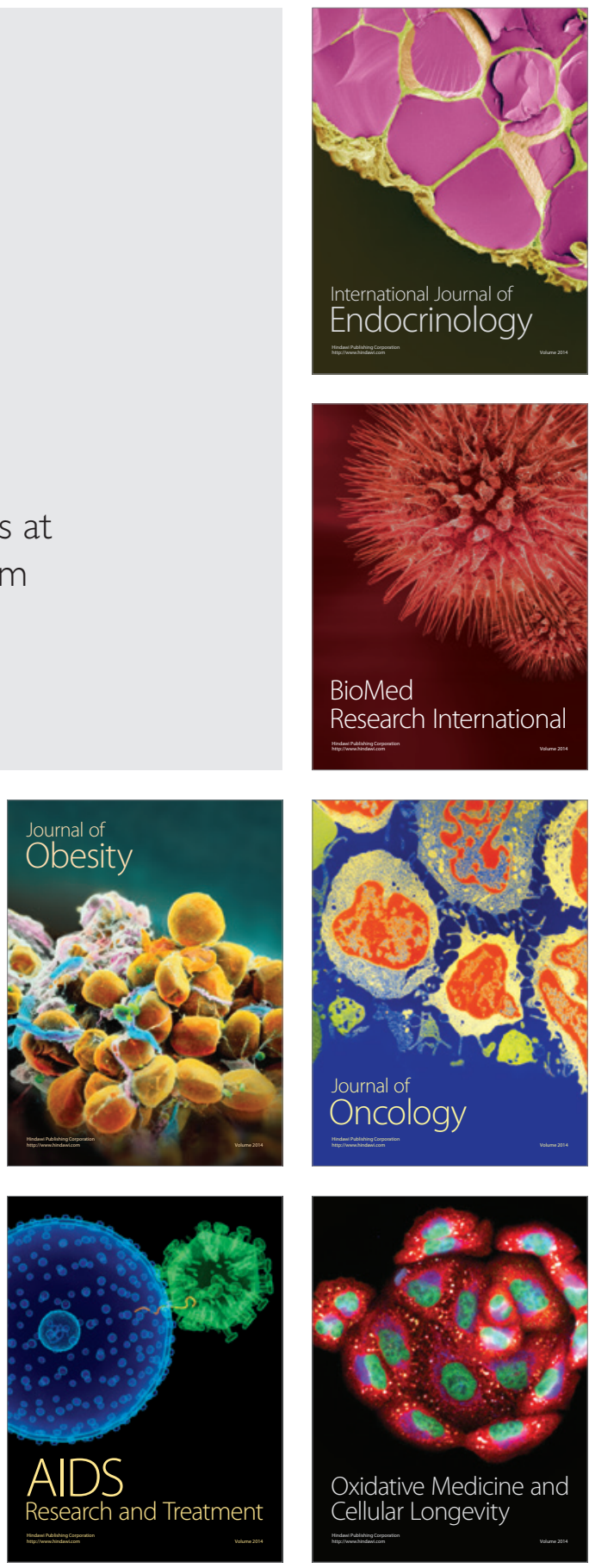